\title{
特集 輸血
}

\section{交 換 輸血一新 生 巟 期-}

志 村 浩 二* 馬 場一雄

\section{はじめに}

新生児期交換輸血の目的は, 新生児重症黄㾝 の治療すなわち，核黄疸の発生防止である。い らまでもなく, 新生児重症黄㾝は脳性麻㽻の成 因として大きな因子をしめており, 有馬ら ${ }^{1)}$ は, 新生児期から追求しえた42例の脳性麻痺例の原 因を推定し,成熟児の $39 \%$ ，未熟児の $26 \%$ が核黄 㾝に起因するという。 Byers ${ }^{2)}$ は脳性麻痺全体 の $5 \%$, 錐体外路性麻痺の $20 \%$ は核黄疸に基つ くと推定している。ささらに Asher は3), アテト 一ゼ型脳性麻痺の $35 \%$ に览間の血液型不適合 を，19\%に血液型不適合のない遷延性黄疸を認 めるといら，馬場ら ${ }^{4)}$ は脳性麻㽻 475 例中 130 例 $(27 \%)$ )遷延性黄疸の既往症が確認されたと い5.

現在，交換輸血以外の新生児重症黄疸の治療 法としては, 光線療法 ${ }^{5) ~ 7), ~ A C T H ~}$ 療法 ${ }^{879)}$,

Phenobarbital 療法 ${ }^{10) 11) ~ な と ゙ か ゙ あ る か ゙ ， こ れ ら ~}$ はいずれも姑息的方法であり，いつでも交換 輸血が行なえるような体制になければならな い.

\section{I. 交換輸血の適応 ${ }^{12) ~ 14)}$}

\section{RH 溶血性疾患}

本症に関しては妊娠中からその発生を予測す ることが可能であり, 羊水分析の結果より子宮 内輸血を行ならことすらある。

一般にビリルビン上昇速度が早いので，以下 の条件を一つでも認めた場合には即刻，交換輸 血を実施すべきである。

* 日本大学医学部小児科

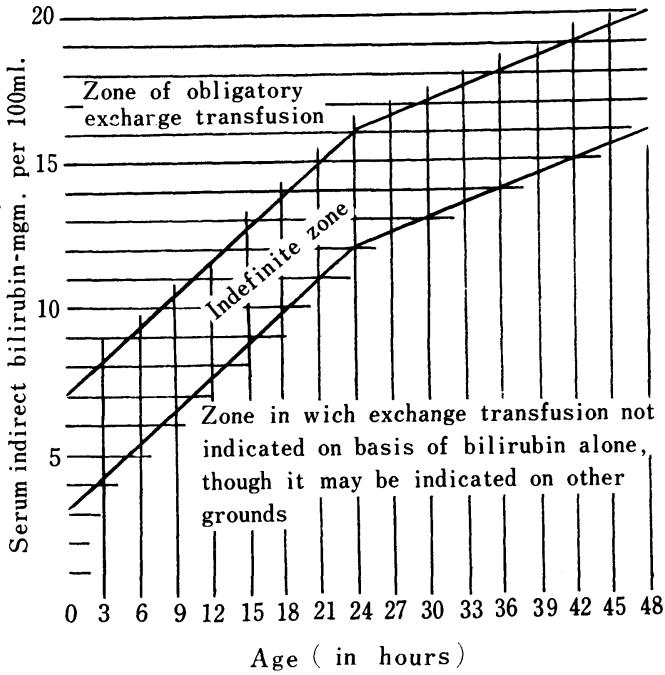

図 1 交換輸血の適応基準

i）出生時血色素量 $15 \mathrm{~g} / \mathrm{d} l$ 以下

ii）臍帯血ビリルビン值 $5 \mathrm{mg} / \mathrm{d} l$ 以上

iii）生後 24 時間以内の末梢血ビリルビン值 10 $\mathrm{mg} / \mathrm{d} l$ 以上

iv) 母血清の抗 $\mathrm{RH}$ 抗体64倍以上

生後24時間以降については， Diamond ${ }^{15)}$ の 図（図 1）に照し合わせて，ビリルビン值が危 険域を越えたならば，直ちに交換輸血を行な 亏.

\section{2. その他の原因による高ビリルビン血症}

i）核黄㾝第 1 期症状の認められた場合 ${ }^{16)}$ 啼泣微弱

哺乳力減退 運動の減少

筋トーヌスの低下

ii）未熟児 : 血清ビリルビン值 $20 \mathrm{mg} / \mathrm{d} l$ 以上 
表 1 使用血液量と交換血の速度

\begin{tabular}{|c|c|c|c|}
\hline 血. 液 量 & \multicolumn{3}{|c|}{$\begin{array}{l}180 \sim 200 \mathrm{ml} / \mathrm{kg} \text { （児の血液量の } 2 \\
\text { 倍） }\end{array}$} \\
\hline \multirow{5}{*}{$\begin{array}{l}1 \text { 回の瀉血 } \\
\text { または輸血 } \\
\text { 量 }\end{array}$} & \multirow[t]{2}{*}{ 成熟児 } & \multicolumn{2}{|c|}{ 低出生体重児 } \\
\hline & & $2000 \mathrm{~g}$ 以上 & $20 \mathrm{ml}$ \\
\hline & & $1501 \sim 2000 \mathrm{~g}$ & $15 \mathrm{ml}$ \\
\hline & $20 \mathrm{~m} l$ & $1001 \sim 1500 \mathrm{~g}$ & $10 \mathrm{ml}$ \\
\hline & & 1000g 以下 & $5 \mathrm{~m} l$ \\
\hline 所 要 時 間 & \multicolumn{3}{|c|}{ 瀉血 2 分, 輸血 2 分 } \\
\hline 全所要時間 & \multicolumn{3}{|c|}{$100 \sim 120$ 分 } \\
\hline
\end{tabular}

成熟児 : 血清ビリルビン值 $25 \mathrm{mg} / \mathrm{d} l$ 以上

iii）以下に示すような Kernicterogenic factors の認められる場合

未熟児 : 血清ビリルビン值 $15 \mathrm{mg} / \mathrm{d} l$ 以上 成熟児 : 血清ビリルビン值 $20 \mathrm{mg} / \mathrm{d} l$ 以上

\section{Kernicterogenic factors}

$\mathrm{ABO}$ 溶血性疾患

アシドーシス

新生児仮死

感染症

呼吸窮迫症候群

低血糖症

低蛋白血症

なお，低出生体重児に拈いてはきわめて低い ビリルビン值に㧍いても核黄疸を呈することが あり 17)18)，また臨床症状も成熟児と異なり，千 アノーゼ, 呷吟, 呼吸数の減少などの呼吸障害 の症状または吐血，下血などの出血傾向を呈す るものが多く, より注意深い観察が必要であ

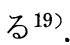

\section{II. 実施上の問題点}

\section{1. 血液の種類}

i) RH 溶血性疾患

$\mathrm{RH}$ 陰性でかつ児と同型または低力価の O 型 の血液が原則であるが，緊急を要することが多 く，血液の入手で手遅れにするよりは $\mathrm{RH}$ 陽 性でかつ児と同型または低力価の $\mathrm{O}$ 型の血液で 交換輸血を行なった方がよい2021).

ii) $\mathrm{ABO}$ 溶血性疾患

$\mathrm{O}$ 型の血球と $\mathrm{AB}$ 型血漿との合成血が理想 22
であるが，実際には複雑な操作を要するため, 低力価 $\mathrm{O}$ 型あるい:同型の血液を使うことさえ ある。

iii）特発性高ビリルビン血症

$\mathrm{ABO}$ 式血液型が患児と同型または $\mathrm{O}$ 型血 液を使用する。

\section{2. 抗凝固剂}

i) Heparin

血液 $100 \mathrm{~m} l$ に対して $2 \mathrm{mg}$ の Heparin を使 用する ${ }^{23)}$. 後述するクエン酸に比し, 電解質異 常, 酸塩基平衡障害がなく, 理想的であるが, 緊急の場合間にあわないことがあり, 一般的に はクェン酸血を使用することが多い。しかし， 著しい低出生体重児や状態が悪く低酸素状態 にある児などの場合には Heparin 血が望まし (24)

ii）クエン酸

一般的には ACD 血が使用される.

この際, クェン酸によるイオン化カルシウム の低下，保存期間に比例して血球より血漿への カリウムの移動による高カリウム血症, 酸塩基 平衡に対する影響としてのアシドーシス, さら にこれらによる心拍出量の減少, 肺静脈圧の上 昇, 心室細動, ショック, 心拍停止などが問題 になる25) 27)。 また，クロールの減少とともに 代謝性アルカローシスを呈してくる28).

以上の副作用に対しては, 少なくとも採血後 5 日以内の血液の使用, $100 \mathrm{~m} l$ ごとに $1 \mathrm{~m} l$ の カルチコールの添加, Slow rate of transfusion により軽減させることはできる ${ }^{26)}$. またアシド ーシスに対してアルカリ剤の添加を良しとする 意見29) もあるが，Late alkalosis を助長させる ことになる恐れがある ${ }^{26)}$.

最近 Papadopoulos，Oski $5^{30)}$ は交换輸血前 後の Hemoglobin-oxygen equilibrium curve, 赤 血球 2·3-DPG を測定, 採血後 24 時間以内の fresh blood と採血 5 日後の “old” blood との 間には血色素の酸素親和性に有意差があり, 交 換輸血にはより新鮮な血液が望ましいという。

\section{3. 交換血液量と交換速度（表 1)}

交換量を多くすればビリルビンの除去量は増 加する。しかしながらより安全に，より効果的 
により短時間にといらことを考慮すると， $200 \mathrm{~m} l / \mathrm{kg}$ の血液量を $2 \mathrm{ml} / \mathrm{kg} / \mathrm{min}$ の速度で交 換することが望ましい(13)31) 33)。すなわち， 20 $\mathrm{m} l$ の交換（䵘血と輸血）に $3 \sim 4$ 分位かけ 100 ～110 分で終了する. 1 回の瀉血量は，患児の 体重状態に応じ増減する必要がある21)（表 1 ）.

\section{4. 体 温}

一般に室温 $28^{\circ} \mathrm{G}$ 前後, 臍部のみ露出した着 衣の成熟新生児では，体温の低下はほとんどみ られないといら ${ }^{34)}$. しかしながら，交換輸血を 施行すると血液を保温しても体温調節が不十分 なため体温は低下してくる. 特に出生直後の新 生児，呼吸障害や心疾患による酸素欠乏時には 著しい，冷たい血液が注入された場合はいうま でもない26).

さらに交換輸血の場合，カテーテルが臍帯よ り $5 \sim 6 \mathrm{~cm}$ 挿入され，心臓に直接注入されるよ らな状態となる，生直後で卵円孔が開存してい る段階では直接左心系, さらに冠状動脈に入 る. 加えて酸性, 低酸素分圧, 低カルシウム, 高カリウムの血液が挿入されれば，心停止を落 起することは容易に想像される。

現在，われわれは患児を室温 $26 \sim 28^{\circ} \mathrm{C}$ の手 術室で, 交換輸血用ベビー・ホルダーに固定, その下に温水灌流マット $\left(36 \sim 38^{\circ} \mathrm{C}\right)$ を敷き， 直腸温を $37^{\circ} \mathrm{G}$ 前後に調節するようにしている.

血液の保温については貯臓びんを暖めても意 味がなく26), 活栓の直前の血液加温器（液温33 $\sim 35^{\circ} \mathrm{C}$ )を通して加温している.

\section{III. 交換輸血の手技}

現在，臍静脈を利用する Diamond 法 ${ }^{35}$ (36)， Fischer \& Oster 法 ${ }^{3738)}$ がもっとも簡易であり, もっとも利用されている。 Boggs ${ }^{39)}$ は臍静脈へ のカテーテル挿入成功率は $98.6 \%$, Panagopoulos は40) $97.5 \%$ であったといい，私達は最近は 開腹手術後の特殊な例を除いては，その他の動 ・静脈を利用する術式41) 43) を用いたことがな い. 以下, 臍静脈使用法について略記する。

\section{1. 臍部の消毒と臍静脈の確保}

臍静脈へのカテーテル捰入に伴う細菌感染は きわめて多く ${ }^{44) 45)}$, 十二分の消毒が 必要であ

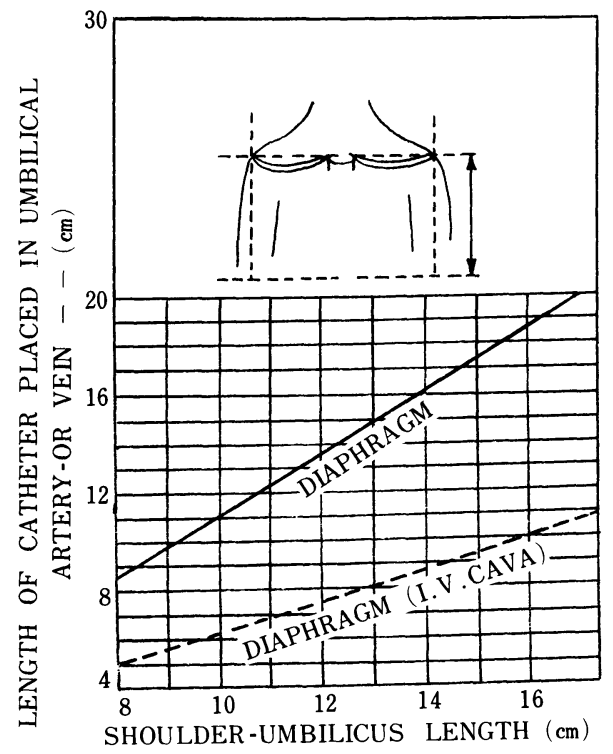

図 2 臍血管カテーテル挿入の指標

る。臍静脈は臍帯脱落前であれば，切断面にも っとも太い血管として，多くは出血を伴い見出 すことができる，臍帯脱落後は鑷子で臍窝を広 げ，外科ゾンデの挿入可能な穴を見つけだすの だが，臍窩が深いとかなりの時間を要する。し かし Pincus 法 ${ }^{41)}$, Wiener 法42などにくらべ, 以後の操作が安全かつ容易に行なえるので, 生 後 2 週間以内ならば努力すべきである.

\section{2. カテーテルの插入}

臍静脈部に凝血を認めたならば，十分に取り 除いた後, 外科ゾンデを挿入, 臍静脈を拡張, カテーテルの挿入を容易にさせる，カテーテル は管腔が太い方が操作が容易である。 カテーテ ルの挿入距離は Shoulder-Umbilicus Length を 指標に Kitterman ら ${ }^{46) \sim 48)}$ のグラフから求める が（図 2)，一般には 5〜 $8 \mathrm{~cm}$ の所で血液が逆 流してくる. $10 \mathrm{~cm}$ 挿入すると先端は心臓の近 くに達するので危険である15)49).

\section{3. 静脈圧の測定}

カテーテルが臍静脈に挿入したら直ちに静脈 圧の測定を行ならのが望をしい，静脈圧は児が 心衰弱, ショック状態にあるか否かを調べるも のであり，カテーテルを垂直に立てた場合，坚 
の腹壁から何 $\mathrm{cm}$ 血液が上昇するかによって簡 単に調べられる。静脈圧は $7 \mathrm{~cm}$ 前後が望まし (15)。静脈圧が $12 \mathrm{~cm}$ 以上ある時は， 1 回ごと の瀉血量をやや多くし，静脈圧を徐々に下げる ようにする。

\section{4. ヘパリンの注入}

輸血にクェン酸血を用いる場合に， ヘパリ ンを注入すると術中にカテーテルのつまること が少ない、へパリンナトリウム 200 単位 $/ \mathrm{kg}$ $(0.2 \mathrm{ml} / \mathrm{kg})$ をカテーテルを通じて注入する.

\section{5. 瀉血と輸血}

交換輸血は瀉血より開始する。吸引に際して は比較的ゆっくり引いた方が, 静脈壁の吸着を 防いでよい. 静脈圧に異常がない限り, 前述し た量, 速度で瀉血・輸血をくりかえす。

\section{6. 交換輸血中の児の観察}

心衰弱とショックに特に注意する。すなわち 頻脈, チアノ一ゼ, 呼吸数の増加, 静脈圧の異 常, 瀉血の色調変化（普通は瀉血は, 酸素にと み, より鮮紅色で, 輸血のそれと対照的である が, 状態が悪い場合には瀉血の色調が黒ずん で，輸血の色調に似てくる.）が認められたら 静脈圧を下げ, 1 回の交換量をへらし, 速度を ゆっくりとし, 児に酸素を与える. 以上の処置 が効を示さない時は中止すべきである ${ }^{32}$.

交換にあたっては瀉血・輸血の量, 回数, 心 拍数, 体温, 呼吸数をチュックしておくべきで ある。

\section{7. グルコン酸カルシウムの注入}

輸血にクェン酸血を用いる場合には, クェン 酸塩注入によっておこる低カルシウ血症を予防 するため, $100 \mathrm{~m} l$ ごとの交換時にカルチコー ル $1 \mathrm{ml}$ の注入を行なう.

\section{8. 硫酸プロタミンの注入}

クエン酸血使用の場合, 最初にヘパリンを注 入したので, 術後約 $15 \%$ が残存している31) と考 え，その作用を中和するために，硫酸プロタミ ソ $0.3 \mathrm{mg} / \mathrm{kg}(0.03 \mathrm{~m} l / \mathrm{kg})$ を注入する.

\section{9. 交換終了時の臍帯の処置}

カテーテルを静かに抜去し, 圧迫止血した後 消毒する。臍帯残部が未乾燥の場合には結禁す る。臍帯が脱落状態の場合には，川筒状に固く
巻いたガーゼを臍部に当て, ガーゼの左右の腹 壁皮膚を絆創膏で中央にひさよせ圧迫包帯とす る。

\section{0. 術後の処置, 養護}

i) 抗生物質

感染防止のため, MPI-PC と AB-PC の合剂 を $100 \mathrm{mg} / \mathrm{kg} / \mathrm{day}, 1$ 日 3 回に分割， 3 日間静 注する。

ii）児の観察

術後少なくとも 12 時間は, 呼吸・脈拍・体温 ・痙攣の有無などに注意する，臍出血の有無を チュックする.

iii）授乳

通常，全身状態良好ならば術後 $4 \sim 6$ 時間に ブドウ糖液を経口投与し, 嘔吐のないことを確 かめてから徐々に授乳を開始する。

\section{IV. 交換輸血に伴う副作用}

\section{1. 交換輸血そのものによる死亡}

Boggs $5^{39)}$ は術中または術後 6 時間以内の死 亡を交換輸血そのものによる死亡とするのが妥 当といら.そして Boggs ${ }^{39)}$ は $2.1 \%$, Odell ${ }^{50)}$ は $0.6 \%$, Panagopoulos ${ }^{40)}$ は $0.66 \%$ の死亡率々 報告している。しかし交換輸血後の経過で死亡 する可能性はこれより大であり，これを加える と $3.1 \sim 4.3 \%$ となる.

出生体重別の死亡率にはほとんど差をみな ( 50$)$ が， RH 溶血性疾患と他の原因によるもの との比較では 6 時間以内の死亡率では前者が $3.5 \%$ 後者が $0.6 \%$ ，全体では $9.8 \%$ と $3.3 \%$ と有意差をみる ${ }^{51)}$.

また死亡率は強度の貧血, 呼吸障害など術前 の状態の悪い症例で高く, $\mathrm{RH}$ 溶血性疾患以外 の原因による高ビリルビン血症の場合には低出 生体重児でもそれほぞ高くはない51)。

\section{2. 感染 症}

感染症として敗血症, 䯣膜炎, 腹膜炎, 骨䯣 炎などの報告をみるが52)，臍帯の消毒がもっと も問題である. 特に生後数日を経過している症 例, 再交換例では污染されている可能性が大き W.

したがって臍帯の十分な消毒, 抗生剤の全身 
表 2 交換輸血の副作用とその予防

\begin{tabular}{|c|c|}
\hline 併 & 防 \\
\hline 型不適合輸血によるショック & 血液型検査 \\
\hline スピード・ショック & 交換時間, 静脈圧測定, 記録 \\
\hline 過負荷による心臓障害 & 速度, カルチコール注入速度, 静脈圧測定, 心電図 \\
\hline 低カルシウム血症 & カルチコール注入, 症状観察, 心電図 \\
\hline 高カリウム血症 & 少なくとも採血後 5 日の血液使用 \\
\hline 失 血 死 & 活栓操作の注意, 瀉血びん計量 \\
\hline 臍静脈穿孔, 門脈血栓 & カテーテル捙入に無理をしない \\
\hline 空気栓 塞 & 静脈圧測定の際に注意 \\
\hline 出血傾向の助長 & ヘパリン血使用に対して硫酸プロタミンの使用 \\
\hline 心拍数 $160 / \mathrm{mi}$. 以上, 心音微 & 静脈圧 $10 \sim 12 \mathrm{~cm}$ 以上, 血液の色に注意 \\
\hline
\end{tabular}

投与, さらには交換終了時の血液培養より薬剤 感受性を検査することなどが必要である。また 臍帯脱落部位の污染がはなはだしいと考えられ る場合は Pincus 法その他による交換輸血が望 ましい。

\section{3. 腸管穿孔}

最近, 腸管穿孔の報告がみられる53/54), 病理 所見は成人にみる acute necrotizing enterocolitis に似ており, 交換輸血中の低血圧, 低酸素, 感 染などが原因として考兄られている。初期症状 は, 哺乳障害, 粘血便の排出・腹部膨満, 胆汁 性嘔吐, 腸雑音の欠除などでこの時期のレント ゲン像は正常あるいは腸管係蹄の拡大といら.

後期になると肺炎を思わせるような臍帯周囲 の浮腫, 発疹, 呷吟, 蒼白, 低体温, 末梢循環 不全をみ，レントゲンでは典型的な横隔膜下遊 離ガス像をみるにいたる53).

\section{4. その他の副作用とその予防 ${ }^{21)}$ (表 2)}

\section{5. 交換輸血後の貧血 ${ }^{55) 56)}$}

交換輸血後 $2 \sim 5$ 週に現われ， RH 溶血性疾 患では, より早期により強く現われる.

低出生体重児は, 成熟児に比し低下が著し く, 6 週頃には血色素量 $5 \sim 6 \mathrm{~g} / \mathrm{d} l$ になる. 赤血球鉄利用率は悪く, 鉄剤投与は無効であ る.
したがって負血のため体重増加悪く, 浮腫を 生じた場合には少量輸血が望ましい。

\section{6. 交換輸血後の肝炎}

小児期の輸血後血清肝炎は少ないといわれて いる.

交換輸血後の肝炎については, 手本の文献で は, 島田 ${ }^{57)}$ の 100 例中の 1 例に術後 $2 \sim 6$ 週に かけ，GOT，GPT が上昇，軽度の黄疸をみた という報告, Kaftanら ${ }^{58)}$ の100例中 1 例に GPT が上昇, 無黄疸性肝炎をみたといら報告, 舟木 $5^{59)}$ の 114 例の予後追跡で死亡 6 例中 5 例（全 体の約 $5 \%$ ）に肝炎をみたといら報告などにす ぎない。

しかしながら舟木らの指摘するよらに予後追 跡や死因の分析が明らかでなく，少ないといわ れる根拠も明確でない現在, 交換輸血後少なく とも $3 \sim 6$ カ月までの血清 GOT, GPT の検査 は, 每血, 精神運動発達のチェックと同様, routine 化して行なわれるべきと考える.

\section{結語}

光線療法, ACTH 療法, Phenobarbital 療法 の有効性は認められているが，その限界をみさ わめ, 時期を失することことなく交換輸血を行 ない, 核黄疸の発生を防止したいものである。 


\section{文献}

1）有馬正高, 他：臨床神経，4；314, 1964.

2) Byers, R.K., et al.: Pediatrics, 15; 248, 1955.

3) Asher, P.: Arch. Dis. Child., 27; 475, 1952.

4）馬場一雄, 他：小児診, 22；923, 1959.

5) Lucey, J., et al.: Pediatrics, 41; 1047, 1968.

6）馬場一雄：小児科, 12(1)；1，1971.

7) 大西鐘寿, 他：小児科, 12(7)；729, 1971.

8）馬場一雄, 他：小児臨， 16(8)；829, 1963.

9）高津忠夫, 他：日児誌, $71(3) ； 372,1967$.

10) Behrman, R. E. et al.: J. Pediat., 76; 945, 1970.

11) Stern, L., et al.: Am. J. Dis. Child., 120; 26, 1970.

12）馬場一雄：新生児溶血性疾患 B . 臨床篇, 日本 血液学全書, 4；562, 1965.

13）馬場一雄：治療, 52(2)；412, 1970.

14）志村浩二：新生児誌, 4(3)；170，1968.

15) Allen, F. H. and Diamond, L. K.: Erythroblastosis fetalis. Little, Brown, Boston and Tronto. 1958.

16) Praagh,, R.V.: Pediatrics, 28; 870, 1961.

17) Gartner, L.M., et al.: Pediatrics, 45(6); 906 , 1970.

18) Ackerman, B. D. et al.: Pediatrics, 45 (6); 1918, 1970.

19）大西鐘寿，他：小児臨, 22(8)；138, 1969.

20）大原俊夫：日本医事新報, No. $2260 ； 163$, 1967.

21）村田交也：産婦実際，17(2)；93, 1968.

22) 小林隆, 高津忠夫編: 新生児研究, 医学畫院, p. 206, 1962.

23) Fischer, K., et al.: Dtsch, Med. Wschr., 86; 1702, 1961.

24）山内逸郎：小児臨，18(5)；593, 1965.

25) Maguire, H., et al.: Acta Pediat. Scand. (Uppsala), 58(5)； 491, 1969.

26) Hey, E.N., et al. : Lancet, 15; 335, 1969.

27）官川 統：産婦治療, 13(1)； 56, 1966.

28) Colladine, M., et al.: Arch. Dis. Child., 40; 626, 1965.

29) Barrie, H.: Lancet, 2; 712, 1965.

30) Papadopoulos, M. D., et al.: J. Pediat., 79 (6); 898, 1971.
31）村田交也：小児科，12(5)；563, 1971.

32）官川 統：産婦治療, 13(1)； 56, 1966.

33) Forfare, J. O., et al.: Exchange transfusion in neonatal hyperbilirubinemia, Lavet., 1131, 1958.

34) Hey, E. N. et al.: Arch. Dis. Child., 45;328, 1970.

35）合瀬徹他：小児臨， 14；1163，1961.

36) Diamond, L.K.: New Eng. J. Med., 244; 39, 1951.

37) Fischer, K., et al.: Msch. Kinderh., 106; 412, 1958.

38）大原俊夫, 他：小児臨， 16；374, 1963.

39) Boggs, T.R.,et al.: Pediatrics, 26; 745, 1960.

40) Panagoboulos, G., et al.: J. Pediat., 74; 247, 1969.

41) Pincus, L.R.: J. Pediat, 33;418, 1948.

42) Wiener, A.S. et al.: J. Lab. Clin. Med., 31; 1016, 1946.

43) Arnold, D. P., et al.: J. Padiat., 32; 113, 1948.

44) Cochran, W. D. et al.: Pediatrics, 42; 769, 1968.

45) Krauss, A. N., et al.: J. Pediat., 77; 965, 1970.

46) Dunn, P.M.: Arch. Dis. Child., 41; 69, 1966.

47) Kitterman, J. A.: Pediat. Clin. N. Amer., 17; 895, 1970.

48）小川雄之亮, 他：小児外科内科, 3; 295, 1971.

49) Erlandson: J. Pediat., 63; 357, 1963.

50) Weldon, V. V., Odell, G. B.: Pediatrics, 41 (4); 797, 1968.

51) Kitchen, W.H.: Aust Paediat. J., 6; 30, 1970.

52) Dortmann, A., et al.: Z. Kinderheilk., 106; 14, 1969.

53) Orme, R. LE. et al.: Brit. M. J., 4; 349, 1968.

54) Hilgertner, M.W., et al.: Am. J. Dis., Child., 120; 79, 1970.

55) Fraser, I.D., et al.: Lancet, 2; 1309, 1964.

56）宮崎澄雄, 他：小览科, 10；563, 1969.

57）島田信宏，他：産婦治療, 19；988, 1969.

58) Kaftan, D., et al.: Arch Kinderheilkd., 181; 119, 1970.

59）舟木憲一, 他：産婦実際，20(4)；337，1971. 